\title{
ALTERNATIVE WOOD SPECIES FOR PLAYGROUNDS WOOD FROM FRUIT TREES
}

\author{
Candan Kus Sahin, Busra Onay \\ Suleyman Demirel University \\ ISPARTA, TURKEY
}

(Received April 2019)

\begin{abstract}
A number of orchard woods have been investigated for suitability in the playgrounds, in the view of responders. In this sense, photos were taken of the specially prepared samples as stimuli, and there were three different groups of respondents. It was observed that the participants were effective in terms of age grouping and material preferences. For group $\mathrm{A}$ and $\mathrm{C}$, majority of the participants preferred wooden elements for playground material. However, the majority of participants in group B (50.5\%) preferred plastic elements, followed by wooden (31.5\%), and then metal (18.0\%). Moreover, it was seen that the most significant factors for selection of material for a playground should be safety for both Group A (79\%), and C (76.5\%), whereas it was aesthetic appearance, for group B (71\%). Similar results were found for color properties of wood - the majority of participants of all three groups preferred light colored wooden elements in playgrounds. The results for the aesthetic preferences of wood species judged one-by-one and judged together received similar results. The preference scores for fig wood (Figus canica) is significantly higher than for other wood species, while "wood color" and "aesthetic appearance" are reliable positive predictors to aesthetic preferences.
\end{abstract}

KEYWORDS: Children playground, wood, hardness, fruit-trees, fig, mulberry, apple, apricot, plum.

\section{INTRODUCTION}

The playground design and equipment are important to keep children happy while still developing their learning abilities. These should be developed in order to suit different age groups of children at different stages of learning. The health benefits of physical activity in children are predominantly noted in the amelioration of risk factors for disease, avoidance of weight gain, achieving a peak bone mass and mental well-being. However, it was concluded that for children ages $0-4$, climbers (40\%) had the highest accident incidence rates, followed by slides (33\%). Moreover, for children ages 5-14, climbing equipment (56\%) had the highest incidence 
rates, followed by swings (24\%), respectively (Tinsworth and McDonald 2001). Furthermore, it was concluded that most injuries on public playground equipment were associated with climbing equipment (53\%), swings (19\%), and slides (17\%) but falls to the ground surface was a contributing factor in 79\% of all injuries (Tinsworth and McDonald 2001).

As a result, they tend to seek out alternative play areas, which may be very unsafe. At the present time, wood has been considered as environmentally friendly material that can be used safely in many specific areas including children's playgrounds. Wood species typically show many advantages over other materials. The wood is a natural material that has an aesthetic appearance and the natural color properties are specific to its own characteristics. Moreover, wood can offer a great range of forms from curved glue-laminated structured members to carved relief pieces. This is due to easy cut and join, and it contrasts with almost any other construction materials that would be difficult to use (i.e., steel, block, concrete). Hence, many kinds of wood-based elements can be manufactured and utilized in city neighborhoods, gardens, parks and playgrounds.

Forests no doubt serve as a source of life for the forest-based industries worldwide. However, due to the shrinking forest areas those industries are facing a wood-shortage problem. There is a need for research into improve durability and use of alternative raw materials for the production of wood-based elements due to the anticipated shortages in the supply of raw materials for the wood-based material industry. There is increasing interest in using wood species from alternative sources, especially fruit-tree woods for many purposes.

Sahin and Mantanis (2011) reported that nanoparticulate based treatment effective for protecting natural colour of some wood species. However, it was proposed that the addition of chips from fruit tree branches to particleboards up to $50 \%$ can be considered successfulsince no appreciable effects on the properties of particleboards were observed (Grigoriou and Passialis 1999). In one research, it was found that olive tree pruning's (OTP) were an interesting raw material for paper production because its properties are comparable to those of the other agricultural residues, currently used in the paper industry (Requejo et al. 2012). Kiaei et al. (2014) studied plum (Prunus domestica) tree to examine its biometrical and chemical properties. Results indicated that there were no significant differences in the chemical properties and fiber length, cell wall thickness and morphological properties when different types of wood (branch and stem) were used. Garcia-Maraver and his group (2015) suggested the best pelleting conditions for the residual biomass from olive trees. Passialis and Grigoriou (1999) again studied the technical properties of branch-wood produced by pruning of fruit-tree plantations (i.e. apple, pear and apricot). From the species that were studied, the branch-wood of apple and pear trees belongs to the diffuse porous group and is characterized by homocellular rays, whilst that of apricot belongs to the ring porous group with heterocellular rays. They found that apple had the larger cell dimensions and apricot trees the shorter/smaller cells. In recent study, Sahin (2010) determined anisotropic swelling and water sorption properties of chesntnut wood which grown in Turkey.

In the Mediterranean areas of southwest Europe, orchard tree pruning generates substantial amounts of residual wood biomass. However, large quantities of branch wood remain in the fields after pruning during the winter period and they are not utilized properly. So far this biomass has not been turned into a useful wood resource. Kiaei et al. (2014) suggested that fruit trees can help solve the problem of the lack of raw materials for the forest products industry. As mention above playgrounds should be act as a more natural environment for the children to play and environmentally friendly wooden material is suitable for such places. However, a present there is no information on utilizing wood from fruit trees in landscape applications.

The objective of this study is to discuss the suitability of some wood species from fruit-trees as the wooden element for certain landscape applications (e.g. playgrounds). Hence we investigated and discuss the aesthetic appearance (color), hardness properties and general specifications of 
selected orchard species. The developments in the use of alternative wood-based material in landscape applications (playgrounds) that use fruit tree wood material for general properties and natural appearance are described in this study. The use of fruit-tree species for playgrounds may create alternative utilization and serve as basis for future studies about those species.

\section{MATERIALS AND METHODS}

The wood-based materials since they are safe and highly suitable for use in children's playgrounds. However, changes over time in some wood species impact if they can meet /satisfy the aesthetic preferences of a landscape practices. Finding out these influences for playgrounds, eight fruit tree wood species that found cultivated/grown in orchards were selected for this study. These are: apple (Malus domestica L.), apricot (Prunus armeniaca), fig (Ficus canica), mulberry (Morus Alba), olive (Olea europaea), pear (Pyrus anatolica), plum (Prunus domestica) and rowanberry (Sorbus aucuparia L.); they were selected for experiments. The selected fruit-tree woods were acquired from the Isparta region in Turkey. Samples of $60 \times 60 \times 20 \mathrm{~mm}$ were prepared and sub-divided into two groups: heartwood and sapwood. The special surface preparation includes sanding to achieve the best appearance.

Progress in the appearance description by means of color and pattern characteristics would be suitable to classify the woods. It would also help to match pieces to study the wood color variability. The quantitative color measurements were carried out with an X-Rite SP 968 spectrophotometer and using CIE L*a*b*c* $h^{*}$ color scale 1976 . The radial and tangential surfaces were measured. The surface whiteness and yellowness color properties were also determined according to standard ASTM E-313, and ASTM D-1925, respectively.

A shore hardness (Scale D) instrument was utilized to measure the hardness properties of the wood samples. The tests were conducted according to the ASTM D-2240 standard. It measures the depth of an indentation in the material created by a given force on a standardized presser foot. This depth is dependent on the hardness of the material and its viscoelastic properties. The measurements were made of five samples in each direction. The average values were then presented as shore hardness of wood samples (Scale D).

Photos of wood species were taken to display to subjects asked for aesthetic assessment and judgment of the suitability of the material for playgrounds during a face-to-face (questionnaire) survey. The photos of eight wood species were taken and stuck to one slide. All of the respondents completed judging natural appearances and their aesthetic preferences based on a slide (Fig. 2).

The face-to-face questionnaire survey method has been intensively used for many kinds of research to collect reliable data. For determining opinion on playgrounds, standard survey questions prepared in advance, were asked to individuals and their answers were recorded. Each survey took about 5.0 minutes to complete. Hence, all respondents were chosen as volunteers and divided into three groups. These are: public people (Group A), children (age level of 5-12 years) (Group B), and university students (undergraduate and graduate) (Group C). Members of the three groups were invited to state their aesthetic preferences for those wood species and to give opinions on playgrounds.

Hands and Brown (2002) suggested that the aesthetic assessment could be divided into 7 ranks (scores). However, there were eight wood species in this study to determine responder's aesthetic preferences. Hence, following scores were chosen to be best applicable in our study. These ranks are; 1: Extremely beautiful; 2: Very beautiful; 3: Beautiful; 4: Moderate; 5: Unbeautiful; 6: Very unbeautiful; 7: Extremely unbeautiful; 8: Unsuitable (awful). The SPSS 13.0 (Statistical 
Program for the Social Sciences) was used to analyze results and these are given in Tabs. and Figs. ANOVA analysis was used to check the differences between the groups. Correlation analysis and stepwise multiple linear regression analysis were conducted to explore the relationships between wood species and aesthetic preferences as well as opinions on playgrounds.

\section{RESULTS AND DISCUSSIONS}

Tab. 1 shows the comparative summary of selected fruit tree wood species including scientific names, densities, hardness (according to Janka) and crushing strength properties. It appears that wood density has a clear effect on the strength properties. The highest crushing strength $(77.1 \mathrm{MPa})$, and hardness $(12.1 \mathrm{kN})$ were reported for the olive tree that has the density value of $0.73 \mathrm{~g} \cdot \mathrm{cm}^{-3}$ in comparison to the other samples. However, apricot and mulberry woods have considerably higher crushing strength of $46.0 \mathrm{MPa}$ and $48.2 \mathrm{MPa}$, respectively. It has already been predicted by a number of researchers that wood having different density properties could influence their strength and hardness properties (Barnett and Jeronimidis 2003, Chowdhury et al. 2012, Kollmann and Côté 1968). Hence, it is assumed that the botanical variations might influence the wood strength properties to some degree in addition to affecting the physical characteristics (density) of woods.

Tab. 1: The properties of some fruit trees.

\begin{tabular}{|l|l|c|c|c|l|}
\hline $\begin{array}{c}\text { Common } \\
\text { name }\end{array}$ & Scientific name & $\begin{array}{c}\text { Density } \\
\left(\mathbf{g} \cdot \mathbf{c m}^{-3}\right)\end{array}$ & $\begin{array}{c}\text { Hardness } \\
(\mathbf{J a n k a )} \mathbf{( k N )}\end{array}$ & $\begin{array}{c}\text { Crushing } \\
\text { strength (MPa) }\end{array}$ & \multicolumn{1}{|c|}{ Reference } \\
\hline Apple & Malus domestica & 0.62 & 7.7 & 41.6 & Meier (2015) \\
\hline Apricot & Prunus armeniaca & 0.75 & 6.9 & 46.0 & Meier (2015) \\
\hline Fig & Ficus canica & 0.39 & - & - & Brown (1997) \\
\hline Mulberry & Morus alba & 0.69 & 7.5 & 48.2 & Meier (2015) \\
\hline Olive & Olea europaea & 0.76 & 12.1 & 77.1 & Meier (2015) \\
\hline Pear & Pyrus anatolica & 0.69 & 7.4 & 44.1 & Meier (2015) \\
\hline Plum & Prunus domestica & 0.62 & 6.2 & 29.3 & $\begin{array}{l}\text { Govarcin et al. } \\
\text { (2012), Meier (2015) }\end{array}$ \\
\hline Rowanberry & Sorbus aucuparia & 0.57 & 6.8 & 22.2 & $\begin{array}{l}\text { Korkut and Guller } \\
\text { (2008) }\end{array}$ \\
\hline
\end{tabular}

Numerous literature on determining biological durability of forest based some wood species (hardwoods and softwoods) has already been reviewed and pointed by a number of researchers. Some excellent bibliographies provide a thorough index to the literature on those sources (EN 350 2016, Golpayegani et al. 2010, Hassan et al. 2018, Mantanis 2017, Meier 2015, Scheffer and Morrell 1998). However, the orchard trees are different trees in a different manner than the traditional forest, and the wood properties can be different as well. Tab. 2 summarizes the biological durability of wood of some fruit trees that has already reported in literature (EN 350 2016, Golpayegani et al. 2010, Hassan et al. 2018, Meier 2015, Scheffer and Morrell 1998). It appears that there some variance in respect to the biological resistance of these woods against fungi, insects (Anobium) and termites. The most resistant against fungi from these fruit species, are actually: Olive wood followed by Mulberry wood. It was reported that Mulberry wood has very high durable properties against insects due to its toxic wood constituents (Hassan et al. 2018). 
Vol. 65 (1): 2020

Tab. 2: Biological durability of wood from some fruit trees.

\begin{tabular}{|c|c|c|c|c|c|}
\hline $\begin{array}{c}\text { Common } \\
\text { name }\end{array}$ & $\begin{array}{c}\text { Scientific } \\
\text { name }\end{array}$ & $\begin{array}{l}\text { Against } \\
\text { fungi }\end{array}$ & $\begin{array}{l}\text { Against } \\
\text { insects }\end{array}$ & $\begin{array}{l}\text { Against } \\
\text { termites }\end{array}$ & Reference \\
\hline Apple & Malus domestica & 4 & $\mathrm{n} / \mathrm{a}$ & $\mathrm{n} / \mathrm{a}$ & EN 350 (2016) \\
\hline Apricot & $\begin{array}{l}\text { Prunus } \\
\text { armeniaca }\end{array}$ & $3-5$ & S & $\mathrm{D}$ & EN 350 (2016) \\
\hline Fig & Ficus canica & Non-durable & Non-durable & $\mathrm{n} / \mathrm{a}$ & $\begin{array}{l}\text { De Guzman and } \\
\text { Siemonsma (1999), } \\
\text { Scheffer and Morrell } \\
\text { (1998) }\end{array}$ \\
\hline Mulberry & Morus alba & Durable & Very durable & $\begin{array}{c}\text { Moderately } \\
\text { durable }\end{array}$ & $\begin{array}{l}\text { Cassens and Makra (2014) } \\
\text { Golpayegani et al. (2010) } \\
\text { Hassan et al. (2018) }\end{array}$ \\
\hline Olive & Olea europaea & Very durable & Non-durable & $\mathrm{n} / \mathrm{a}$ & Meier (2015) \\
\hline Pear & Pyrus anatolica & Non-durable & $\mathrm{n} / \mathrm{a}$ & $\mathrm{n} / \mathrm{a}$ & Meier (2015) \\
\hline Plum & $\begin{array}{l}\text { Prunus } \\
\text { domestica }\end{array}$ & $3-4$ & S & $\mathrm{D}$ & EN 350 (2016) \\
\hline Rowanberry & Sorbus aucuparia & Non-durable & $\mathrm{n} / \mathrm{a}$ & $\mathrm{n} / \mathrm{a}$ & Palm et al. (2005) \\
\hline
\end{tabular}

The graphical plots of wood density versus hardness (Shore D) (Fig. 1) show a basic trend similar to that in Tab. 1. It is known that increasing density usually affects hardness positively on all woods. However, the highest hardness was measured for olive wood (74), followed by apricot (70), pear (64) and mulberry (63). Wiemann and Green (2007) suggested that the hardness and specific gravity relationship is a phenomenological parameter which is determined by both its density and botanical origin. They suggested that wood-density and hardness display an approximately similar trend for tropical and temperate hardwoods, but that the relationship for softwoods is different from that for hardwoods. Moreover, the wood hardness properties are not well understood for most wood species. To determine the hardness, one has to understand factors such as: wood anatomical structure, chemical content and growing conditions.

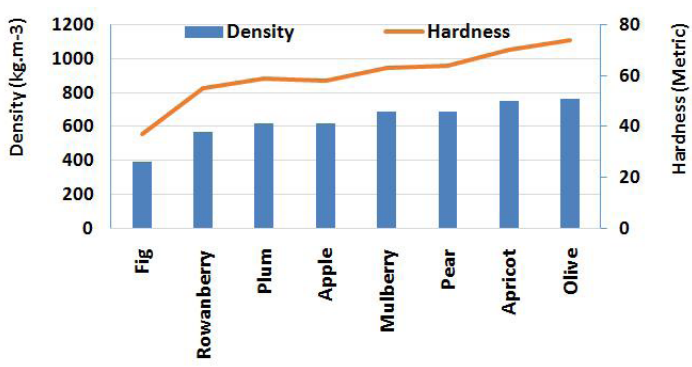

Fig. 1: Wood density and hardness properties of fruit tree wood species.

Tab. 3 summarizes the color values of wood species. It appears that there are clear variations in color properties of selected wood species. The highest lightness values of (L*) 87.25 were observed for fig followed by mulberry (74.47) and pear (73.35), respectively. In contrast, the lowest lightness values of 51.57 were observed for apricot samples. Moreover, the green-red $\left(\mathrm{a}^{*}\right)$ and yellow-blue $\left(\mathrm{b}^{*}\right)$ color coordinates were also considerable variations among species. 
For a* properties, except fig which shows only negative values of $(-3.67)$ which means green is dominant in its natural color, all other wood species show positive values $(+a)$ and that means red is dominant in their natural color. However, as mentioned above, the color properties of wood are not well understood for most wood species. Hence, variations among color patterns of wood specimens are very complicated and it is not intended (possible) to explain all color characteristics. It should be emphasized that the determination of $\mathrm{a}^{*}$ and $\mathrm{b}^{*}$ must be considered as being only suggestive intimating / hinting / alluding.

The $\mathrm{C}^{*}$ represents Chroma or 'saturation' properties of a given color. The Chroma is the strength of an object color and describes the vividness or dullness of a color. However, the high Chroma (saturation) represents 'color purity' and both hue angle and chroma both relate to human color perception. As seen in Tab. 3 the highest chroma value was observed for apricot (66.59), followed by fig (26.06), plum (22.6), olive (20.53), pear (18.82), rowanberry (17.38), apple (15.89) and mulberry (14.7), respectively.

The $\boldsymbol{H}^{*}\left({ }^{\circ}\right)$ represents the angle of the line starting from the point to the zero origin in CIE $L^{*}, a^{*}, b^{*}$ color space. It is basically the degree to which a stimulus can be described as similar to or different from stimuli that are described as: red, yellow, green and blue or a combination of two of them. Hence, hue is the attribute of color that is related to the perceived colors. The units are in the form of degrees ${ }^{\circ}$ (or angles), ranging from $0^{\circ}$ (red) through $90^{\circ}$ (yellow), $180^{\circ}$ (green), $270^{\circ}$ (blue) and back to $0^{\circ}$. The highest hue value (degree) was observed for fig $\left(98.1^{\circ}\right)$, followed by mulberry $\left(80.28^{\circ}\right)$, pear $\left(80.17^{\circ}\right)$, rowanberry $\left(76.92^{\circ}\right)$, olive $\left(71.15^{\circ}\right)$, apple $\left(68.89^{\circ}\right)$, and apricot $\left(21.35^{\circ}\right)$, respectively.

Tab. 3: Colour properties of fruit tree wood samples (CIE $L^{*} a^{*} b^{*}$, 1976).

\begin{tabular}{|l|c|c|c|c|c|c|c|}
\hline Wood species & $\mathbf{L}^{*}$ & $\mathbf{a}^{*}$ & $\mathbf{b}^{*}$ & $\mathbf{C}^{*}$ & $\left.\mathbf{H} \mathbf{(}^{\circ}\right)$ & $\begin{array}{c}\text { Whiteness } \\
\text { (ASTM-E313) }\end{array}$ & $\begin{array}{c}\text { Yellowness } \\
\text { (ASTM-D1925) }\end{array}$ \\
\hline Apple & 54.27 & 5.72 & 14.82 & 15.89 & 68.89 & 6.5 & 47.68 \\
\hline Apricot & 51.57 & 9.54 & 22.04 & 66.59 & 21.35 & 17.06 & 71.05 \\
\hline Fig & 87.25 & -3.67 & 25.83 & 26.06 & 98.1 & 35.07 & 43.79 \\
\hline Mulberry & 74.47 & 2.48 & 14.49 & 14.7 & 80.28 & 0.61 & 34.07 \\
\hline Olive & 57.65 & 6.63 & 19.43 & 20.53 & 71.15 & 14.46 & 57.02 \\
\hline Pear & 73.35 & 3.21 & 18.54 & 18.82 & 80.17 & 12.53 & 43.02 \\
\hline Plum & 54.9 & 9.24 & 20.63 & 22.6 & 65.87 & 15.95 & 64.87 \\
\hline Rowanberry & 58.88 & 3.93 & 16.93 & 17.38 & 76.92 & 10.02 & 47.61 \\
\hline
\end{tabular}

Whiteness is defined as a measure of how closely a surface matches the properties of a perfect reflecting diffuser, the highest whiteness indices was found for fig (35.07) whereas the lowest whiteness was found for mulberry (0.62). However, yellowness is defined as a measure of the degree to which the color of a surface is shifted from preferred white towards yellow. It can be seen in Tab. 3 that apricot has a very high yellowness value of 71.05, compared to other wood species.

Fig. 2 shows the natural appearance of fruit tree species. However, colors with the same hue are usually distinguished with adjectives referring to their lightness and/or colorfulness, such as with "light color", "pastel color", "vivid color". Interestingly, apple and plum; mulberry and pear; olive and rowanberry are more or less similar (approx. \pm 0.11 to 7.0 differences) L*, $a^{*}, b^{*}$, chroma and hue values. Hence these wood species could be described as having similar color properties. However, it should be noticed that the determination of exact color properties of a given wood is very complicated and it is not intended to determine exact color properties of the wood samples. It should be emphasized that the given color parameters could be considered as being only suggestive. 
It has already been thoroughly emphasized that wood's natural appearance could have an important role in many applications (i.e. architecture practices) and supports the selection of wooden elements. Therefore, the scientific appreciation and evaluation of the aesthetic characters can help to better understand the reasons for the wood species preferences and why people prefer a certain piece of wooden decoration for the playgrounds. This assessment process contained two steps. The first step was general material selection preferences assessment for playground use. The second step was judging the natural appearance of wood as shown in Fig. 2.
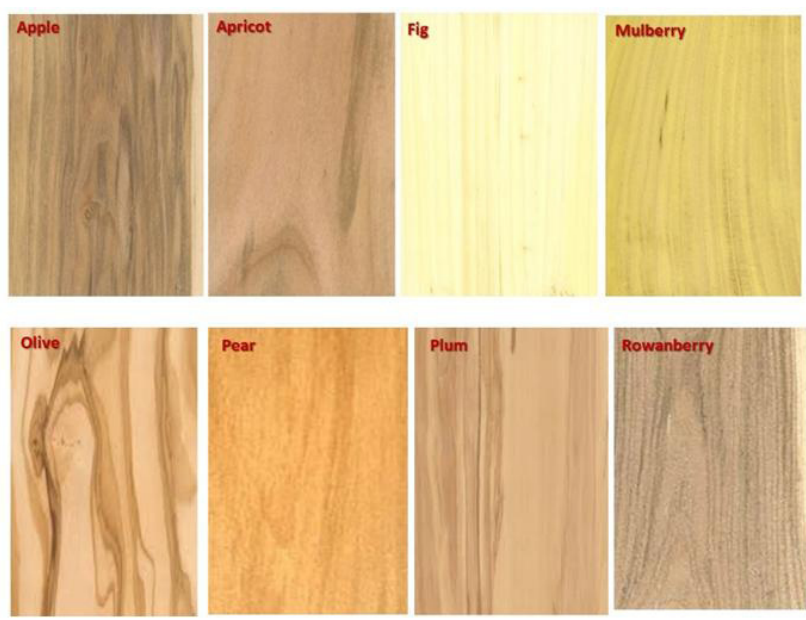

Fig. 2: The natural appearance of fruit tree wood samples (Meier, 2015).

Survey data of participant's demographic characteristics obtained as a result of face-toface survey application are shown in Tab. 4. A total of 600 individuals (200 from each group) participated in the survey. It was observed that the participants were effective in terms of age group and material preferences. For group A, majority of the participants (45\%) preferred wooden elements for playground material, followed by plastic (42.0\%), metal (13.0\%), in order of importance. For group C, the recorded order of importance materials preferences were similar. However, for group $\mathrm{B}$, some differences were found in material selection. The majority of participants in group B (50.5\%) preferred plastic elements, followed by wooden (31.5\%), metal (18.0\%), and other material (0.02\%), for playgrounds.

However, it was seen that the most effective factors for selection of material for playground should be security for both Group A (79\%), and C (76.5\%), whereas aesthetic appearance was selected by group B (71\%). Similar results were also found for color properties of woods a majority of participants of both group A and C preferred light-colored wooden elements in playgrounds. The group B participants almost equally (46\% vs. $42.5 \%)$ preferred light and dark colored wooden elements in playgrounds.

Stamps (1999) proposed that students can substitute for the public in landscape assessment. However, Yao et al. (2012) also suggested that there was no significant difference between undergraduate students and the public for aesthetic assessment. The results found in this study clearly support this information. 
Tab. 4: The demographic properties of respondents.

\begin{tabular}{|c|c|c|c|}
\hline & $\begin{array}{c}\text { Group A } \\
\text { (Public people) }\end{array}$ & $\begin{array}{c}\text { Group B } \\
\text { (Children) }\end{array}$ & $\begin{array}{c}\text { Group C } \\
\text { (University students) }\end{array}$ \\
\hline \multicolumn{4}{|c|}{ Gender } \\
\hline Male & $82(41 \%)$ & $96(48 \%)$ & $98(49 \%)$ \\
\hline Female & $118(59 \%)$ & $104(52 \%)$ & $102(51 \%)$ \\
\hline \multicolumn{4}{|c|}{ Age groups } \\
\hline Years old & $\begin{array}{c}\text { 20-29: } 69 \\
\text { 30-39: } 45 \\
40-49: 43 \\
\text { 50-59: } 28 \\
>60: 14\end{array}$ & $\begin{array}{c}<5: 15 \\
\text { 6-8: } 69 \\
\text { 9-12: } 101 \\
>12: 15\end{array}$ & $\begin{array}{c}\text { 17-21: } 114 \\
\text { 22-26: } 74 \\
\text { 27-31: } 5 \\
>32: 7\end{array}$ \\
\hline \multicolumn{4}{|c|}{ Material preferences for playgrounds } \\
\hline a: Plastic & $84(42.0 \%)$ & $101(50.5 \%)$ & $79(39.5 \%)$ \\
\hline b: Wood & $90(45.0 \%)$ & $63(31.5 \%)$ & $115(57.5 \%)$ \\
\hline c: Metal & $26(13.0 \%)$ & $36(18.0 \%)$ & $6(3.0 \%)$ \\
\hline \multicolumn{4}{|c|}{ Reason for selecting that material for playgrounds } \\
\hline $\begin{array}{l}\text { a: Should be secure for } \\
\text { children } \\
\text { b: Should be longer } \\
\text { service time } \\
\text { c: Should be aesthetic } \\
\text { appearance } \\
\text { d: Should be cheap }\end{array}$ & $\begin{array}{c}158(79.0 \%) \\
26(13.0 \%) \\
14(7.0 \%) \\
2(1.0 \%)\end{array}$ & $\begin{array}{c}32(16.0 \%) \\
18(9.0 \%) \\
142(71.0 \%) \\
8(4.0 \%)\end{array}$ & $\begin{array}{c}153(76.5 \%) \\
10(5.0 \%) \\
33(16.5 \%) \\
4(2.0 \%)\end{array}$ \\
\hline \multicolumn{4}{|c|}{ What colour properties of woods should have } \\
\hline a: Light colored & $127(63.5 \%)$ & $92(46.0 \%)$ & $140(70.0 \%)$ \\
\hline b: Dark coloured & $61(30.5 \%)$ & $85(42.5 \%)$ & $51(25.5 \%)$ \\
\hline c: No preferences & & & \\
\hline
\end{tabular}

However, in order to assess the aesthetic appearance of woods in playgrounds, the participants were asked questions regarding wood's scoring (rank) according to their natural appearance. Tab. 5 shows the scores of woods according to natural appearance. It must be understood that the scoring of wood appearance is very complicated and it is not intended to explain/ take into account all the variances.

Only the fig wood was scored to have the extremely beautiful natural appearance, which is very attractive to use in playground applications by wood of all these three groups. This is not surprising considering the color properties of fig wood that are grouped as having a light colored (Fig. 2) appearance. This result also supports the finding for the preferences of color properties of woods. Hence the majority of participants in these three groups preferred light colored wooden elements in playgrounds. According to results presented in Tab. 5, it is not easy to measure aesthetic appearance of wood samples. However, the results indicate that wood with good/attractive appearance were mostly found among light colored wood species. 
Vol. 65 (1): 2020

Tab. 4: The scores of woods according to natural appearance (1: Extremely beautiful, 2: Very beautiful, 3: Beautiful, 4: Moderate, 5: Unbeautiful, 6: Very unbeautiful, 7: Extremely unbeautiful, 8: Unsuitable (awful).

\begin{tabular}{|c|c|c|c|}
\hline & $\begin{array}{c}\text { Group A } \\
\text { (Public people) }\end{array}$ & $\begin{array}{l}\text { Group B } \\
\text { (Children) }\end{array}$ & $\begin{array}{c}\text { Group C } \\
\text { (University } \\
\text { students) }\end{array}$ \\
\hline \multirow{2}{*}{ Woods } & \multicolumn{3}{|c|}{ Valid questionnaires (persons) } \\
\hline & 189 & 154 & 193 \\
\hline Apple (Malus domestica L.) & $\begin{array}{c}\text { 1: } 33(17.5 \%) \\
\text { 2: } 15(7.9 \%) \\
\text { 3: } 9(4.8 \%) \\
4: 13(6.9 \%) \\
\text { 5: } 15(7.9 \%) \\
\text { 6: } 21(11.1 \%) \\
\text { 7: } 41(21.7 \%) \\
\text { 8: } 42(22.2 \%) \\
\text { C }\end{array}$ & $\begin{array}{c}\text { 1: } 2(1.3 \%) \\
\text { 2: } 12(7.9 \%) \\
\text { 3: } 9(5.8 \%) \\
\text { 4: } 10(6.5 \%) \\
\text { 5: } 19(12.3 \%) \\
\text { 6: } 20(13.0 \%) \\
7: 36(23.4 \%) \\
\text { 8: } 32(20.8 \%) \\
\text { AB }\end{array}$ & $\begin{array}{c}1: 31(16.1 \%) \\
2: 14(7.3 \%) \\
\text { 3: } 15(7.8 \%) \\
4: 26(13.5 \%) \\
5: 28(14.5 \%) \\
\text { 6: } 24(12.4 \%) \\
7: 30(15.5 \%) \\
8: 26(13.5 \%) \\
\text { BCD }\end{array}$ \\
\hline Apricot (Prunus armeniaca) & $\begin{array}{c}\text { 1: } 10(11.2 \%) \\
2: 5(2.6 \%) \\
\text { 3: } 35(18.5 \%) \\
4: 28(14.8 \%) \\
5: 33(17.5 \%) \\
\text { 6: } 35(18.5 \%) \\
7: 7(3.7 \%) \\
8: 8(4.2 \%) \\
\text { BC }\end{array}$ & $\begin{array}{c}\text { 1: } 18(11.7 \%) \\
\text { 2: } 10(6.5 \%) \\
\text { 3: } 22(14.3 \%) \\
\text { 4: } 17(11.0 \%) \\
\text { 5: } 19(12.3 \%) \\
\text { 6: } 41(26.6 \%) \\
7: 12(7.8 \%) \\
\text { 8: } 12(7.8 \%) \\
\text { CD }\end{array}$ & $\begin{array}{c}\text { 1: } 12(6.2 \%) \\
2: 23(11.9 \%) \\
\text { 3: } 37(19.2 \%) \\
\text { 4: } 33(17.1 \%) \\
\text { 5: } 31(16.1 \%) \\
\text { 6: } 24(12.4 \%) \\
\text { 7: } 19(9.8 \%) \\
\text { 8: } 11(5.7 \%) \\
\text { BC }\end{array}$ \\
\hline Fig (Ficus canica) & $\begin{array}{c}\text { 1: } 69(36.5 \%) \\
\text { 2: } 23(12.2 \%) \\
\text { 3: } 11(5.8 \%) \\
\text { 4: } 8(4.2 \%) \\
\text { 5: } 9(4.8 \%) \\
\text { 6: } 13(6.9 \%) \\
7: 19(10.1 \%) \\
\text { 8: } 37(19.6 \%) \\
\text { AB }\end{array}$ & $\begin{array}{c}\text { 1: } 57(37.0 \%) \\
\text { 2: } 19(12.3 \%) \\
\text { 3: } 17(11.0 \%) \\
4: 7(4.5 \%) \\
\text { 5: } 11(7.1 \%) \\
\text { 6: } 7(4.6 \%) \\
7: 12(7.8 \%) \\
\text { 8: } 24(15.6 \%) \\
\text { A }\end{array}$ & $\begin{array}{c}\text { 1: } 48(24.9 \%) \\
\text { 2: } 17(8.8 \%) \\
\text { 3: } 8(4.1 \%) \\
4: 18(9.3 \%) \\
5: 15(7.8 \%) \\
6: 26(13.5 \%) \\
7: 29(15.0 \%) \\
\text { 8: } 32(16.6 \%) \\
\text { BCD }\end{array}$ \\
\hline Mulberry (Morus alba) & $\begin{array}{c}\text { 1: } 9(4.8 \%) \\
\text { 2: } 54(28.6 \%) \\
\text { 3: } 13(6.9 \%) \\
4: 22(11.6 \%) \\
5: 13(6.9 \%) \\
\text { 6: } 24(12.7 \%) \\
7: 32(16.9 \%) \\
\text { 8: } 22(11.6 \%) \\
\text { BC }\end{array}$ & $\begin{array}{c}\text { 1: } 24(15.6 \%) \\
\text { 2: } 36(23.4 \%) \\
\text { 3: } 24(15.6 \%) \\
\text { 4: } 14(9.1 \%) \\
\text { 5: } 10(6.5 \%) \\
\text { 6: } 21(13.6 \%) \\
\text { 7: } 23(14.9 \%) \\
\text { 8: } 12(7.8 \%) \\
\text { ABC } \\
\end{array}$ & $\begin{array}{c}1: 10(5.2 \%) \\
2: 29(15.0 \%) \\
\text { 3: } 17(8.8 \%) \\
4: 17(8.8 \%) \\
\text { 5: } 24(12.4 \%) \\
6: 32(16.6 \%) \\
7: 37(19.2 \%) \\
8: 27(14.0 \%) \\
\text { CD } \\
\end{array}$ \\
\hline
\end{tabular}




\begin{tabular}{|c|c|c|c|}
\hline Olive (Olea europaea) & $\begin{array}{c}\text { 1: } 11(5.8 \%) \\
\text { 2: } 19(10.1 \%) \\
\text { 3: } 28(14.8 \%) \\
\text { 4: } 36(11.6 \%) \\
\text { 5: } 43(22.8 \%) \\
\text { 6: } 29(15.3 \%) \\
\text { 7: } 11(5.8 \%) \\
\text { 8: } 12(6.3 \%) \\
\text { BC }\end{array}$ & $\begin{array}{c}\text { 1: } 7(4.5 \%) \\
\text { 2: } 11(7.1 \%) \\
\text { 3: } 21(13.6 \%) \\
\text { 4: } 40(26.0 \%) \\
\text { 5: } 31(20.1 \%) \\
\text { 6: } 17(11.0 \%) \\
\text { 7: } 14(9.1 \%) \\
\text { 8: } 12(7.8 \%) \\
\text { ABCD }\end{array}$ & $\begin{array}{c}\text { 1: } 30(15.5 \%) \\
\text { 2: } 13(6.7 \%) \\
\text { 3: } 23(11.9 \%) \\
\text { 4: } 21(10.9 \%) \\
\text { 5: } 34(17.6 \%) \\
\text { 6: } 23(11.9 \%) \\
7: 21(10.9 \%) \\
\text { 8: } 23(11.9 \%) \\
\text { BCD }\end{array}$ \\
\hline Pear (Pyrus anatolica) & $\begin{array}{c}\text { 1: } 7(3.7 \%) \\
\text { 2: } 17(8.9 \%) \\
\text { 3: } 33(17.5 \%) \\
\text { 4: } 26(13.8 \%) \\
\text { 5: } 29(15.3 \%) \\
\text { 6: } 36(19.1 \%) \\
\text { 7: } 21(11.1 \%) \\
\text { 8: } 20(10.6 \%) \\
\text { C }\end{array}$ & $\begin{array}{c}\text { 1: } 11(7.1 \%) \\
\text { 2: } 30(19.5 \%) \\
\text { 3: } 23(14.9 \%) \\
\text { 4: } 17(11.0 \%) \\
\text { 5: } 14(9.1 \%) \\
\text { 6: } 21(13.6 \%) \\
\text { 7: } 27(17.5 \%) \\
\text { 8: } 11(7.1 \%) \\
\text { ABCD }\end{array}$ & $\begin{array}{c}\text { 1: } 13(6.7 \%) \\
\text { 2: } 12(6.2 \%) \\
\text { 3: } 21(10.9 \%) \\
\text { 4: } 22(11.4 \%) \\
\text { 5: } 24(12.4 \%) \\
\text { 6: } 34(17.6 \%) \\
\text { 7: } 28(14.5 \%) \\
\text { 8: } 39(20.2 \%) \\
\text { D }\end{array}$ \\
\hline Plum (Prunus domestica) & $\begin{array}{c}\text { 1: } 35(39.3 \%) \\
\text { 2: } 28(14.8 \%) \\
\text { 3: } 40(21.2 \%) \\
\text { 4: } 31(16.4 \%) \\
\text { 5: } 34(17.9 \%) \\
\text { 6: } 12(6.3 \%) \\
\text { 7: } 5(2.6 \%) \\
\text { 8: } 8(4.2 \%) \\
\mathbf{A}\end{array}$ & $\begin{array}{c}\text { 1: } 26(16.9 \%) \\
\text { 2: } 14(9.1 \%) \\
\text { 3: } 20(12.3 \%) \\
\text { 4: } 31(20.1 \%) \\
\text { 5: } 34(22.1 \%) \\
\text { 6: } 10(6.5 \%) \\
\text { 7: } 9(5.8 \%) \\
\text { 8: } 10(6.5 \%) \\
\text { AB }\end{array}$ & $\begin{array}{c}\text { 1: } 24(12.4 \%) \\
\text { 2: } 38(19.7 \%) \\
\text { 3: } 41(19.2 \%) \\
\text { 4: } 37(19.3 \%) \\
\text { 5: } 28(14.5 \%) \\
\text { 6: } 11(5.7 \%) \\
\text { 7: } 8(4.1 \%) \\
\text { 8: } 6(3.1 \%) \\
\text { A }\end{array}$ \\
\hline Rowanberry (Sorbus aucuparia L.) & $\begin{array}{c}\text { 1: } 13(6.9 \%) \\
\text { 2: } 27(14.3 \%) \\
\text { 3: } 20(10.6 \%) \\
\text { 4: } 25(13.2 \%) \\
\text { 5: } 12(6.3 \%) \\
\text { 6: } 24(12.7 \%) \\
\text { 7: } 27(14.3 \%) \\
\text { 8: } 41(21.7 \%) \\
\text { C }\end{array}$ & $\begin{array}{c}\text { 1: } 13(8.4 \%) \\
\text { 2: } 21(13.6 \%) \\
\text { 3: } 18(11.7 \%) \\
\text { 4: } 19(12.3 \%) \\
\text { 5: } 19(12.3 \%) \\
\text { 6: } 14(9.1 \%) \\
\text { 7: } 20(13.0 \%) \\
\text { 8: } 30(19.5 \%) \\
\text { BCD }\end{array}$ & $\begin{array}{c}\text { 1: } 22(11.4 \%) \\
\text { 2: } 35(18.5 \%) \\
\text { 3: } 27(14.0 \%) \\
\text { 4: } 26(13.5 \%) \\
\text { 5: } 17(8.8 \%) \\
\text { 6: } 26(13.5 \%) \\
7: 19(9.8 \%) \\
\text { 8: } 22(11.4 \%) \\
\text { AB }\end{array}$ \\
\hline
\end{tabular}

\section{CONCLUSIONS}

It is important to select suitable materials for children's playgrounds. However, it was realized that the factors for selection of material for a playground were security and aesthetic appearance. For wood materials; color and natural appearance are found to be important predictors to aesthetic preferences. It appears that there are clear variations on color properties of selected fruit-tree wood species. It was understood that wood appearance or preferences was associated with responders of different age groups and who belong to different professions. It is important to note that the majority of participants preferred light colored wooden elements in playgrounds. 
The use of fruit tree woods has not yet been considered to be used for the manufacture of wood-based elements in playgrounds. This study may provide preliminary data for landscaping improvement of playgrounds using fruit tree woods.

\section{ACKNOWLEDGEMENTS}

The author wishes to thank Professor Abdullah Sutcu from the Isparta University of Applied Sciences for statistical analyses of obtained data.

\section{REFERENCES}

1. Barnett, J.R., Jeronimidis, G., 2003: Wood quality and its biological basis. Blackwell Scientific Publisher, 226p. Oxfordshire, UK, 226 pp.

2. Brown, S., 1997: Estimating biomass and biomass change of tropical forests: a primer. FAO Forestry Paper 134, Rome, 55 pp.

3. Cassens, D., Makra, E., 2014. Urban wood and traditional wood: a comparison of properties and uses. FNR-490-W, Purdue University Extention, IL. 13 pp.

4. Chowdhury, M.Q. Ishiguri, F., Hiraiwa, T., Matsumoto, K., Takashima, Y., 2012: Variation in anatomical properties and correlations with wood density and compressive strength in Casuarina equisetifolia growing in Bangladesh. Australian Forestry 75(2): 95-99.

5. Deborah, K.T., McDonald, J.E., 2001. Special study: injuries and deaths associated with children's playground equipment. Directorate for Epidemiology, U.S. Consumer Product Safety Commission, Washington, $37 \mathrm{pp}$.

6. De Guzman, C. C., Siemonsma, J. S.(Eds). 1999.Species Prosea. Plant resources of SouthEast Asia 13: Backhuys Publishers, Leiden, Netherlands, 400 pp.

7. EN 350, 2016: Durability of wood and wood-based products. Testing and classification of the durability to biological agents of wood and wood-based products.

8. Garcia-Maraver, A., Rodriguez, M.L., Serrano-Bernardo, F., Diaz, L.F., Zamorano, M., 2015: Factors affecting the quality of pellets made from residual biomass of olive trees. Fuel Processing Technology 129: 1-7.

9. Golpayegani, A.S., Thevenon, M.F., Gril, J., Pourtahmasi, K., 2010: Natural durability of Mulberry wood from Iran. In 41st Annual Meeting of the International Research Group on Wood Protection. Biarritz, France, 9-13 May 2010. IRG Secretariat.

10. Govorcin, S., Sinkovic, T., Sedlar, T., Istok, I., Vukadin, M., 2012: Some physical and mechanical properties of plum tree (Prunus Domestica L.). Drvna Industrija 63 (4): 291-295.

11. Grigoriou, A., Passialis, C., 1999: Utilization of branch-wood from fruit-tree plantations for particleboard production. Holz als Roh-und Werkstoff 52 (2): 126-130.

12. Hassan, B., Mankowski, M.E., Kirker, G.T., Clausen, C.A., Ahmed, S., 2018: Effects of white mulberry (Morus alba) heartwood extract against Reticulitermes flavipes (Blattodea: Rhinotermitidae). Journal of Economic Entomology 111(3): 1337-1345.

13. Janin, G., Goncalez, J., Ananias, R., Charrier, B., da Silva, G.F., Dilem, A., 2001: Aesthetics appreciation of wood colour and patterns by colorimetry. Part 1. Colorimetry theory for the CIELab system. Maderas: Ciencia y Technologia 3(1/2): 3-11.

14. Kiaei, M., Tajik, M., Vaysi, R., 2014: Chemical and biometrical properties of plum woods and its application in pulp and paper production Maderas. Ciencia y Tecnología 16 (3): 312-332. 
15. Kollmann, F.R., Côté, W.A., 1968: Principles of Wood Science and Technology. SpringerVerlag, Berlin, Germany, 592 pp.

16. Korkut, S., Guller, B., 2008: Physical and mechanical properties of European hophornbeam (Ostrya carpinifolia Scop.) wood. Bioresorce Technology 99: 4780-4785.

17. Mantanis, G.I. 2017: Chemical modification of wood by acetylation or furfurylation: A review of the present scaled-up technologies. BioResources 12(2): 4478-4489.

18. Meier, E., 2015: Wood! Identifying and using hundreds of woods worldwide. The Wood Database, USA, 31 pp.

19. Scheffer, T.C., Morrell, J.J. 1998: Natural durability of wood: a worldwide checklist of species. Oregon State Univesity, Forest Research Laboratory., Research Contribution, Corvallis, $62 \mathrm{pp}$.

20. Palm, J., Åhström, A., Wijk, G., Johansson, S., 2005: Hardwoods-The facts, Träcentrum Nässjö (Wood Centre Nässjö) Sweden, 43 pp.

21. Passialis, C.N, Grigoriou, A.H., 1999: Technical properties of branch-wood of apple, peach, pear, apricot and cherry fruit trees. Holz als Roh-und Werkstoff 57(1): 41-44.

22. Requejo, A., Rodriguez, A., Colodette, J.L., Gomide, J.L., Jimenez, L., 2012: TCF bleaching sequence in kraft pulping of olive tree pruning residues. Bioresource Technology 117: $117-123$.

23. Sahin, H. T., Mantanis, G. I. 2011. Colour changes in wood surfaces modified by a nanoparticulate based treatment. Wood Research, 56 (4): 525-532.

24. Sahin, H. T. 2010. Experimental determination of the anisotropic swelling and water sorption properties of chesntnut wood. Wood Research 55(1): 33-40.

25. Wiemann, M.C., Green, D.W., 2007: Estimating Janka hardness from specific gravity for tropical and temperate species. USDA Forest Service, FPL-RP-643. Madison, WI. 21 pp.

\author{
Candan Kus Sahin*, Busra Onay \\ Suleyman Demirel University \\ Faculty of Architecture \\ Department of Landscape Architecture \\ DoĞU Kampusu, 32260 Isparta \\ TURKeY \\ *Corresponding author: candansahin@sdu.edu.tr
}

